\title{
Polyphasic Identification of Amylolytic Bacteria Producing Bioplastic Poly- $\beta$-hydroxybutyrate (PHB)
}

(Pengenalpastian Polifasa Bakteria Amilolisis Menghasilkan Bioplastik Poli- $\beta$-hidroksibutirat (PHB))

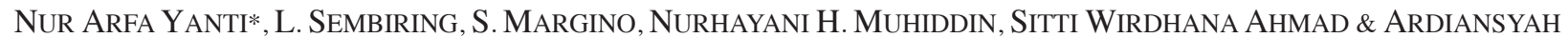

\begin{abstract}
The final goal of this study is to make a modern systematic-based inventory of amylolytic bacterial isolates producing of bioplastic Poly- $\beta$-hydroxybutyrate ( $(\mathrm{HB})$ from sago starch substrate. The identity of three local bacterial isolates was examined in this study, using a polyphasic approach. A data set based on phenotypic characteristics, namely morphological, physiological, biochemical and chemical character, namely whole cells protein profiles using SDS-PAGE method, together with phylogenetic studies based on $16 S$ rRNA sequences was used to identified by polyphasic approach. Phenotypic characteristics of 3 local bacterial isolates and 4 reference strains to members of genus Bacillus was analyzed by numerical analysis using MVSP 3,1 program to determine the value of similarity. Based on the preliminary characterization of the profile matching method showed that the three isolates of bacteria producing PHB namely PSAlO, PPK5 and PPK6 are members of the genus Bacillus. The results of numerical analysis based on phenotypic characteristic and chemical character of the three bacterial isolates producing PHB with reference strains showed that the PSA10 isolate bacterial identical with Bacillus megaterium, PPK5 isolate identical with Bacillus subtilis and PPK6 isolate identical with Bacillus cereus, and these results also support by the molecular phylogenetic analysis. Therefore, the polyphasic taxonomy is an effective approach to uncover the identity of the novel bacterial isolates.
\end{abstract}

Keywords: Amylolytic bacteria; bioplastic; numeric-phenetic; PHB; polyphasic

ABSTRAK

Matlamat akhir kajian ini adalah untuk membuat inventori berasaskan sistematik moden daripada pencilan bakteria amilolisis yang menghasilkan bioplastik Poli- $\beta$-hidroksibutirat (PHB) daripada substrat kanji sagu. Identiti tiga pencilan bakteria tempatan telah diperiksa dalam kajian ini, menggunakan pendekatan polifasa. Satu set data berdasarkan ciricirifenotip, iaitu sifat morfologi, fisiologi, biokimia dan kimia, iaitu profil protein sel keseluruhan menggunakan kaedah SDS-PAGE, bersama-sama dengan kajian filogenetik berdasarkan urutan $16 S$ rRNA digunakan untuk mengenal pasti dengan pendekatan polifasa. Ciri-ciri fenotip 3 pencilan bakteria tempatan dan 4 rujukan kepada ahli genus Bacillus dianalisis dengan analisis berangka menggunakan MVSP 3,1 program untuk menentukan nilai keserupaan. Berdasarkan pencirian permulaan kaedah pencocokan profil menunjukkan bahawa tiga pencilan bakteria yang menghasilkan PHB iaitu PSA10, PPK5 dan PPK6 adalah ahli genus Bacillus. Hasil analisis berangka berdasarkan pencirian fenotip dan sifat kimia ketiga pencilan bakteria yang menghasilkan PHB dengan strain rujukan menunjukkan bahawa PSA10 seiras dengan Bacillus megaterium, PPK5 seiras dengan Bacillus subtilis dan PPK6 seiras dengan Bacillus cereus, dan keputusan ini juga disokong oleh analisis filogenetik molekul. Oleh itu, taksonomi polifasa adalah pendekatan yang berkesan untuk mendedahkan identiti novel pencilan bakteria.

Kata kunci: Bakteria amilolisis; bioplastik; numerik-fenetik; PHB; polifasa

\section{INTRODUCTION}

Poly- $\beta$-hydroxybutyrate (PHB) is a polymer produced by microorganisms that could potentially be used as raw material for plastics. Utilization of PHB as raw plastic materials, more environmentally friendly because it is easily degraded naturally (Lenz \& Marchesault 2005; Shivalkar \& Prabha 2017). Various bacterial strains among Archaebacteria, Gram positive, Gram negative bacteria and Cyanobacteria have been identified to accumulate PHB using various substrates (Chee et al. 2010; Ray \& Kalia 2016). However, not many bacteria capable of converting complex substrates, such as starch into PHB.
Exploration bacteria capable of producing bioplastic PHB using a wide variety of substrates starch has been conducted (Aremu et al. 2010; Shivakumar 2012; Yanti et al. 2013). Three bacterial isolates namely PSA10, PPK6 and PPK5, were isolated from sago processing area in Konawe regency Southeast Sulawesi, Indonesia and they were known to able produce PHB from sago starch substrate (Yanti et al. 2009). Utilization of isolates PSA10, PPK5 and PPK6 which is a local bacterial origin of Southeast Sulawesi, Indonesia as a manufacturer of bioplastic PHB, need to be characterized and identified properly, so that the identity and authenticity can be justified scientifically. The 
bacterial isolates were identified from the standpoint of the polyphasic approach, particularly based on morphological, physiological, biochemical and chemical characters as the phenotypic criteria and 16S rRNA gene sequences as the genotypic criteria (Logan et al. 2002; Mainville et al. 2006; Randazzo et al. 2009).

Chemical character at the level of protein based on a comparative analysis of protein profiles can be used for rapid microbial identification (Berber 2004; Berber $\&$ Yenidunya 2005). The whole cell of bacteria protein profiles produced by SDS-PAGE have been observed to correlate closely with DNA-DNA hybridization results and to be suitable for rapid bacterial identification (Priest et al. 1988; Vauterin et al. 1993). High resolution polyacrylamide gel electrophoresis (PAGE) of proteins with computerized analysis of profiles provided an effective approach to the investigation of taxonomic relationships among many bacterial species (Berber 2004; Berber \& Yenidunya 2005). Several investigators have used SDSPAGE of soluble bacterial polypeptides data for numerical taxonomy and an effective approach to the investigation of taxonomic relationships among many bacterial species (Berber 2004; Berber \& Yenidunya 2005; Ghazi et al. 2009; Santos et al. 2012; Sarkono et al. 2016). Therefore, this study aimed to identify the three isolates of bacterial producing bioplastics from Southeast Sulawesi, Indonesia by polyphasic taxonomy approach, particularly based on the characters of phenotypic, whole cell protein profile and genotypic characters, so as to illustrate the similarities between bacterial and the identity of the local bacterial isolates can be unveiled.

\section{MATERIAL AND METHODS}

\section{BACTERIAL STRAINS AND GROWTH CONDITION}

Three local amylolytic bacterial isolates producing of bioplastic PHB, namely isolates PSA10, PPK5 and PPK6 and 4 reference strains used in this study. Reference strains used were members of the genus Bacillus namely B. subtilis ATCC 6051, B. pumilus ATCC 700814, B. cereus ATCC 14579 , and B. megaterium FNCC 0083. The bacterial strains rejuvenated at medium Nutrient Agar (NA) and then incubated at $30^{\circ} \mathrm{C}$ during $24 \mathrm{~h}$.

\section{DETERMINATION OF AMYLOLYTIC BACTERIA}

The ability of the bacteria to hydrolyze starch (amylolytic) was initially tested on starch agar containing $0,3 \%(\mathrm{w} / \mathrm{v})$ of starch. The clear zone around the colony was measured upon pouring iodine. The assay for measuring the amylase activity was determined by using the procedure described by Espino and Tambalo (1997).

\section{DETECTION OF PHB-PRODUCING BACTERIA}

Bacterial ability accumulated PHB was detected macroscopically, using Sudan black staining method.
Macroscopic observation of PHB-producing bacteria were carried out by growing bacterial isolates on modified minimal media, composed of $\left(1^{-1}\right.$ aquadest $): 0,8 \mathrm{~g}$ $\left(\mathrm{NH}_{4}\right)_{2} \mathrm{SO}_{4}, 2,4 \mathrm{~g} \mathrm{KH}_{2} \mathrm{PO}_{4}, 2 \mathrm{~g} \mathrm{Na}_{2} \mathrm{HPO}_{4}, 0,5 \mathrm{~g} \mathrm{NaHCO}_{3}$, $0,8 \mathrm{~g}$ yeast extract, $8 \mathrm{~g}$ sago starch, $5 \mathrm{~g}$ glucose, 0,08 Amonium Iron (III) Citrate, $0,2 \mathrm{~g} \mathrm{MgSO}_{4} \cdot 7 \mathrm{H}_{2} \mathrm{O}, 15 \mathrm{~g}$ agar. The bacterial isolates were incubated at $30^{\circ} \mathrm{C}$ for $48 \mathrm{~h}$. Bacterial colonies that grown on a minimal medium, was stained with Sudan black $0.02 \%$ (b/v) dissolved in $96 \%$ ethanol for $10 \mathrm{~min}$ and then washed with $100 \%$ ethanol. Bacterial colonies that accumulate PHB would absorb Sudan black so that it was blackish blue while bacterial colonies were unable to accumulate PHB, did not absorb Sudan black. In this test, the bacterial strain was unable to accumulate PHB namely Escherichia coli ATCC 25922 which was used as negative control.

\section{PRODUCTION AND DETERMINATION OF POLY-B- HYDROXYBUTYRATE (PHB)}

Production of PHB by three local isolates were done using modified minimal media Ramsay with sago starch as carbon source (Yanti et al. 2013) and were incubated at $150 \mathrm{rpm}$ for $72 \mathrm{~h}$ at $30^{\circ} \mathrm{C}$. Harvesting and measuring of PHB was done by using the procedure was described by Yanti et al. (2013).

\section{PRELIMINARY IDENTIFICATION BY PROFILE MATCHING METHOD}

Three isolates of bacteria producing PHB were characterized the properties of phenotypic according Smibert and Krieg (1994), all the characters of the three bacterial isolates verified with key characters of the specific genus, using Bergey's Manual of Determinative Bacteriology (Holt et al. 1994) to ensure the genus of the third isolates with a profile matching method.

\section{PHENOTYPIC CHARACTERIZATION}

The phenotypic properties such as nitrate reduction, citrate assimilation, MR-VP reaction, growth at different temperatures as well as the ability to grow in different concentrations of sodium chloride and $\mathrm{pH}$ in Nutrient broth, were done according to Smibert and Krieg (1994). Sugar fermentation patterns of bacterial isolates were determined using the API 50CHB test strips (BioMerieux, France).

\section{CHEMICAL CHARACTERIZATION}

Identification of 3 bacterial isolates with a chemical characterization was based on finger printing of whole-cell protein that are visualized using Sodium Dodecyl Sulphate poliacrylamide gel electrophoresis (SDS PAGE) (Scopes 1987). Marker protein was used is a product Fermentas (Fermentas life sciences). Total protein fingerprint profiles between the bacterial strains were analyzed numerically to determine the value of similarity. 


\section{NUMERIC-PHENETIC ANALYSIS}

Numerical analysis performed to classify bacterial strains and determine the value of the similarity between the bacterial strains. Data phenotypic and chemical characters were analyzed using Multi-variate statistical package (MVSP) Plus-version 3.1 (Kovacs Computing Service 1990). Similarity value is determined using simple matching coefficient (SSM), and the grouping is done by algorithms UPGMA (Unweighted Pair Group Method with arithmetic Averages). The results were presented as a dendrogram analysis (Jamili et al. 2016a).

\section{GENOTYPIC CHARACTERIZATION}

Identification of bacterial isolates based on genotypic characterization was conducted by $16 \mathrm{~S}$ rRNA sequence comparison. Genomic DNA from bacterial isolates were obtained as described by Song et al. (2004). Amplification of $16 \mathrm{~S}$ rRNA by PCR was done using universal bacterial primer 27f (5'-AGAGTTTAGTCCTGGCTCAG-3') and 1529R (5'-CAIAAAGGAGGTGATCC-3'). PCR product was checked in $2 \%(\mathrm{w} / \mathrm{v})$ agarose gel electrophoresis. The PCR product was purified using microclean kit (Microzone Ltd.). Purified 16S rDNA was sequenced using ABI PRISM 310 big dye terminator cycle sequence reading reaction kit, according to the protocol of the manufacturer (Applied Biosystems). Base sequences were determined in an Applied Biosystems model 310 genetic analyzer.

The 16S rRNA sequence of bacterial isolates were aligned with representative bacteria $16 \mathrm{~S}$ rRNA sequences retrieved from the NCBI nucleotide sequence database (http://www.ncbi.nlm.nih.gov) and was edited manually. Pairwise evolutionary similarities and distances were computed by using the DNADIST program in the phylogeny inference package (PHYLIP) versi on 3,5 (Felsenstein 1995). The phylogenetic tree was constructed by using the Neighbour-joining algorithm (Saitou \& Nei 1987). The root position of unrooted tree was estimated by using Paenibacillus amylolyticus JCM $9906^{\mathrm{T}}$ as the outgroup strain.

\section{RESULTS AND DISCUSSION}

\section{AMYLOLYTIC BACTERIAL PRODUCING PHB}

Three local bacterial isolates from Southeast Sulawesi, namely PPK5, PPK6 and PSA10 were able to hydrolyze of starch (amylolytic), were indicated by the formation of clear zone around bacterial colonies on starch agar media (Figure 1(A)). Figure 1(B) shows that the three bacterial colonies (PPK5, PPK6 and PSA10) were blackishblue because they absorbed Sudan black stain. This result indicated that the three local bacteria isolates are capable to accumulate PHB in the cells. This indication is strengthened by bacterial colonies of negative control was colorless (Figure 1(B)). Sudan black stain has a high affinity for PHB granules, so that bacterial cell capable of producing PHB would be stained (Ostle \& Holt 1982).

The amylase enzyme activity and PHB content were produced from sago starch media by three local bacterial isolates were listed in Table 1.

The three local bacterial isolates were able produce PHB from sago starch as much as 10,83\% - 52,28\% (PHB of $\mathrm{CDW}$ ) at $72 \mathrm{~h}$ incubation. Table 1 shows that PPK5 isolate has the highest of amylase enzyme activity but the lowest of PHB content, whereas PSA10 isolate has the highest PHB content. The ability of the three local

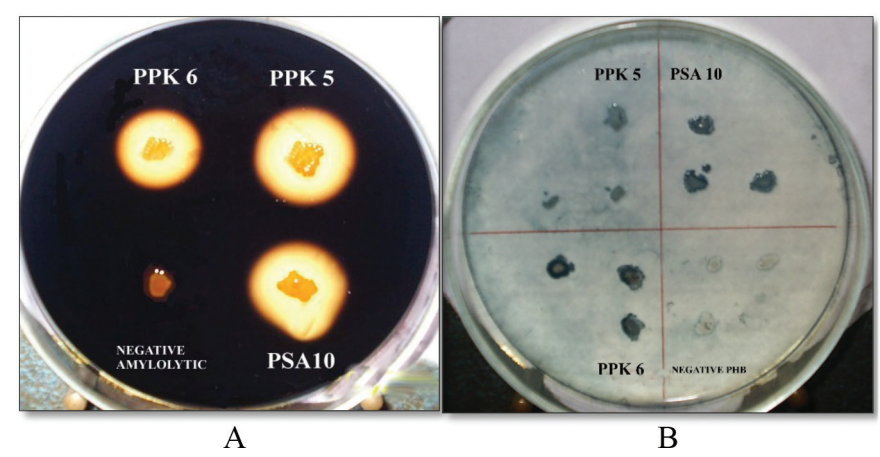

FIGURE 1. Qualitative determination of amylolitic bacterial and PHB producing bacterial. A. Amylolytic Bacterial, B. PHB-producing bacterial. Negative control: Escherichia coli ATCC 25922

TABLE 1. Amylase enzyme activity and production of PHB from sago starch of the three local bacterial isolates

\begin{tabular}{ccc}
\hline Bacterial isolate & $\begin{array}{c}\text { Amylase enzyme activity } \\
(\mathrm{DUN} / \mathrm{mL})\end{array}$ & $\begin{array}{c}\text { PHB content } \\
(\% \text { PHB of cell dry weight })\end{array}$ \\
\hline PPK5 & 99,30 & 10,83 \\
PPK6 & 21,81 & 30,90 \\
PSA10 & 42,74 & 52,28 \\
\hline
\end{tabular}


bacterial isolates produced amylase enzyme, causing the bacterial were capable produce PHB using sago starch substrate directly. Utilization of amylolitic bacteria as PHB producer, is very prospective to be developed because it is able to use complex substrate which is cheaper than glucose as main substrate in PHB production (Chee et al. 2010; Halami 2008). Therefore, identification of these bacterial isolates is very important for further utilization.

\section{DETERMINATION OF REFERENCE STRAINS BY PROFILE MATCHING METHOD}

The aim of this preliminary characterization to determine the reference strains to be used in the identification stage. The use of the reference strain identification stage serves as a comparison so that the identification can be justified.

Based on the preliminary characterization of the profile matching method in Table 2, shows that isolate PSA10, PPK5 and PPK6 identical with the character of the genus Bacillus. All three bacterial isolates were a Gram positive, rod-shaped, form endospores, motile and catalase positive and these characters corresponding to the key character of the genus Bacillus (Holt et al. 1994). Thus, the three isolates are members of the genus Bacillus.

Based on the results at the level of genus profile matching, it is determined that the reference strains used are species of the genus Bacillus members. Species references selected in this study are Bacillus subtilis, Bacillus cereus and Bacillus megaterium. The three species were chosen because the references has been known to hydrolyze starch (Holt et al. 1994) and accumulate PHB (Halami 2008; Singh et al. 2009; Visnuvardhan et al. 2008). In this study, Bacillus pumilus used also as a reference species to represent members of the genus Bacillus which has a different character with the three reference species selected. O'Donnell et al. (1980) states that B. pumilus is a member of the genus Bacillus that can not hydrolyze starch and accumulate PHB.

\section{IDENTIFICATION OF THE AMYLOLYTIC BACTERIA PRODUCING OF PHB BY PHENOTYPIC CHARACTERS ANALYSIS}

The results of the phenotypic characters, such as morphological, biochemical and physiological study of microorganism are shown in Table 3. Phenotypic characters were analyzed based on phenetic-numeric systematics are a total of 77 characters. The results of the characterization of bacterial strains were listed in Table 3 . The results of phenetic-numeric analysis of phenotypic characters are visualized in the dendrogram, is shown in Figure 2.

Dendrogram based on similarity value of amylolytic bacteria producing PHB with 4 reference Bacillus strains in Figure 2, shows that there are four clusters were formed. Two clusters with similarity value of $92.6 \%$, namely cluster 1 comprised of PSA10 isolate with $B$. megaterium FNCC 0083 and cluster 2 comprised of PPK5 isolate with B. subtilis ATCC $6051^{\mathrm{T}}$. Cluster 3 with a similarity value of $90.1 \%$, comprised of PPK6 isolate and B. cereus ATCC $14579^{\mathrm{T}}$ and cluster 4 is a single cluster consisted of $B$. pumilus ATCC 700814. The results of identification based on a numerical systematic analysis by phenotypic characters in Figure 2, indicated that PSA10 isolate identical to $B$. megaterium, PPK6 isolate identical to B. cereus and РPK5 isolate identical to B. subtilis. Priest et al. (1988) states that the high similarity value of bacterial strain, shows the high similarity level among bacterial strains. The similarity value of bacterial strain based on phenotypic characters is $\geq 80 \%$ (Logan et al. 2002; Priest et al. 1988).

Isolate of PSA10 has a cell size larger than both the other isolates, with the cell width of $1.5 \mu \mathrm{m}$ (Table 2) and this character matches with the key character of $B$. megaterium which has a cells width of more than $1 \mu \mathrm{m}$ (Priest et al. 1988; Slepecky \& Hemphill 2006). The ability of PPK6 isolate to reduce $\mathrm{NO}_{3}$ to $\mathrm{NO}_{2}$ (Table 3) is a character that makes the PPK6 isolate was identical to $B$. cereus. Slepecky and Hemphill (2006) states that the key character that distinguish between $B$. cereus with $B$. subtilis and $B$. megaterium is able to reduce $\mathrm{NO}_{3}$ to $\mathrm{NO}_{2}$. Character of PPK5 isolate which is aerobic, is the character
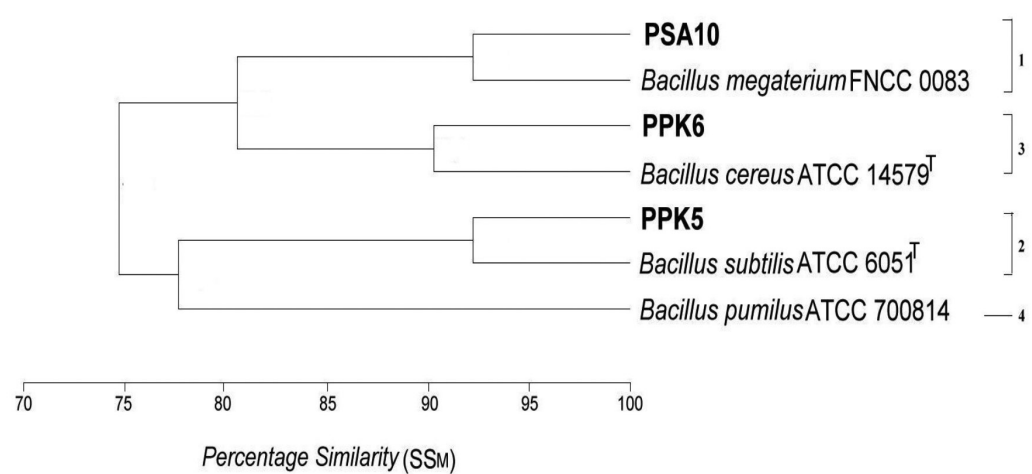

FIGURE 2. The dendrogram showing the phenetic relationship between 3 local amylolytic bacteria isolates and 4 representatives of the Bacillus species based on simple matching coefficient $\left(\mathrm{SS}_{\mathrm{M}}\right)$ analysis and unweighted pairgroup method with arithmetic average (UPGMA) algorithm based on phenotypic characters 
TABLE 2. Identification of genus (generic assignment) the local amylolytic bacteria producing PHB with reference genus Bacillus based on profile matching method

\begin{tabular}{|c|c|c|c|c|}
\hline Characters & PSA10 & PPK5 & PPK6 & Genus Bacillus $^{\mathrm{a}}$ \\
\hline Cell shape: Rod (Bacil) & + & + & + & + \\
\hline Gram reaction & + & + & + & + \\
\hline Motility & + & + & + & + \\
\hline Endospora & + & + & + & + \\
\hline Catalase & + & + & + & + \\
\hline Width of $\operatorname{rod}(\mu \mathrm{m})$ & 1,5 & 0,8 & 1 & $0,5-\geq 1$ \\
\hline
\end{tabular}

a Description of key characters of genus Bacillus based on Bergey's manual determinative of bacteriology (Holt et al. 1994).

TABLE 3. Phenotypic characters of the local amylolytic bacteria producing of bioplastic and reference strains

Characters

Morphology characteristics

Colony shape circulair

Cell size : cell width $\geq 1 \mu \mathrm{m}$

Cell Arrangement : Streptobacil

Biochemical properties

Citrate assimilation

Nitrate reduction

Gelatin Hydrolysis

Casein Hydrolysis

Starch Hydrolysis

Tween 80 Hydrolysis

PHB accumulation

(\% g PHB/g cell dry weight)

Methyl Red reaction

Voges Proskauer reaction

Sugar Fermentation (API $50 \mathrm{CHB}$ )

Glycerol

Erythritol

D-Arabinosa

L-Arabinosa

D-Ribose

D-Xylose

L-Xylose

D-Adonitol

Methyl- $\beta$ D-Xylopyranoside

D-Galactose

D-Glucose

D-Fructose

D-Mannose

L-Sorbose

L-Rhamnose

Dulcitol

Inositol

D-Manitol

D-Sorbitol

Methyl- $\alpha$ D Mannopyranoside

Methyl- $\alpha$ D-Glucopyranoside

$\mathrm{N}$-Acetylglucosamine

Amygdalin

+
+
+

-
-
-
+
+
+
+

$\begin{array}{ll}+ & + \\ - & +\end{array}$

+
+
+

(52.28)

$(10,83)$

$(30,90)$

$(5,32)$

$(5,86)$

,06)

(0)

$\begin{array}{lll}+ & + & - \\ + & - & +\end{array}$


(Continued) TABLE 3.

\begin{tabular}{|c|c|c|c|c|c|c|c|}
\hline \multirow[b]{2}{*}{ Characters } & \multicolumn{7}{|c|}{ Local bacteria isolates and reference strains } \\
\hline & $\begin{array}{l}\stackrel{0}{\mathbb{L}} \\
\stackrel{2}{2}\end{array}$ & $\frac{n}{\frac{n}{2}}$ & $\begin{array}{l}0 \\
\frac{1}{a} \\
a\end{array}$ & 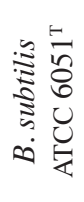 & 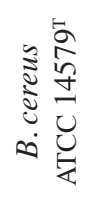 & 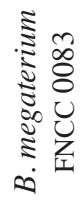 & 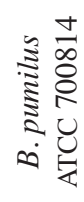 \\
\hline Arbulin & + & + & + & + & + & + & + \\
\hline Esculin tetric citrate & + & + & + & + & + & + & + \\
\hline Salicin & + & + & + & + & + & + & + \\
\hline D-Celibiose & + & + & + & + & + & + & + \\
\hline D-Maltose & + & + & + & + & + & + & - \\
\hline D-Lactose (Bovine origin) & + & + & - & + & - & + & - \\
\hline D-Melibiose & + & - & + & - & - & - & - \\
\hline D-Saccharose (Sucrose) & + & + & + & + & + & + & + \\
\hline D-Trehalose & + & + & + & + & + & + & + \\
\hline Inulin & - & - & - & - & - & - & - \\
\hline D-Melezitose & - & - & - & - & - & - & - \\
\hline D-Rafinose & + & + & + & - & - & + & - \\
\hline Amidon (Starch) & + & + & + & + & + & + & - \\
\hline Glycogen & + & + & + & + & + & + & - \\
\hline Xylitol & - & - & - & - & - & - & - \\
\hline Gentiobiose & + & - & + & - & + & + & - \\
\hline D-Turanose & + & - & - & - & - & - & - \\
\hline D-Lyxose & - & - & - & - & - & - & - \\
\hline D-Tagatose & - & - & - & - & - & - & - \\
\hline D-Fucose & - & - & - & - & - & - & - \\
\hline L-Fucose & - & - & - & - & - & - & - \\
\hline D-Arabitol & + & - & - & - & - & + & - \\
\hline L-Arabitol & - & - & - & - & - & - & - \\
\hline Potassium Gluconate & - & - & - & - & - & - & - \\
\hline Potassium 2-ketogluconate & - & - & - & - & - & - & - \\
\hline Potassium 5-ketogluconate & - & - & - & - & - & - & - \\
\hline \multicolumn{8}{|c|}{ Physiological properties } \\
\hline \multicolumn{8}{|c|}{ Growth in NB medium containing $\mathrm{NaCl}$} \\
\hline $5 \%$ & + & + & + & + & + & + & + \\
\hline $7 \%$ & - & + & + & + & + & - & + \\
\hline $10 \%$ & - & + & - & + & + & - & - \\
\hline \multicolumn{8}{|l|}{ Growth at temperature $\left({ }^{\circ} \mathrm{C}\right)$} \\
\hline 5 & - & - & - & + & + & - & + \\
\hline 15 & + & - & + & + & + & - & + \\
\hline $30-50$ & + & + & + & + & + & + & + \\
\hline \multicolumn{8}{|l|}{ Growth at $p H$} \\
\hline 4 & - & + & - & + & + & + & + \\
\hline $5-8$ & + & + & + & + & + & + & + \\
\hline \multicolumn{8}{|l|}{$\mathrm{O}_{2}$ Requirement } \\
\hline Aerob & - & + & - & + & - & - & + \\
\hline Facultative Anaerob & + & - & + & - & + & + & - \\
\hline
\end{tabular}

that is identical with B. subtilis (Table 3). Slepecky and Hemphill (2006) states that $B$. subtilis is not capable of growing in anaerobic conditions.

IDENTIFICATION OF THE AMYLOLYTIC BACTERIA PRODUCING OF PHB BY CHEMICAL CHARACTER (WHOLECELL PROTEIN PROFILES) ANALYSIS

The whole-cell protein profiles of the reference Bacillus strains and native amylolytic bacteria strains were obtained by SDS-PAGE and its diagramatic representative are shown in Figure 3. Diagramatic representative of cellular protein profiles, was constructed using the Paint Shop Pro program. The protein profiles were inspected visually and compared with each other.

Data of the protein bands on diagramatic representative numerically analyzed based on the Simple Matching Coefficient (SSM) and the algorithm based on Unweighted Pair Group Method with Arithmetic Average Algorithm 
(UPGMA) to be constructed in the form dendrogram (Figure 3). Similarity matrix and cluster analysis between amylolytic bacteria producing of PHB with reference strains based on the whole-cell protein profiles, were listed in Table 4.

Based on the dendrogram was shown in Figure 4 is known that there are three clusters formed. The first cluster comprised of four strains, namely strain PSA10, PPK6, $B$. megaterium $\mathrm{FNCC} 0083$ and B. cereus $\mathrm{ATCC} 14579^{\mathrm{T}}$ with the similarity value of $75.9 \%$. Isolates PSA 10 and PPK6 joined in a cluster on the similarity value of $83.3 \%$. B. megaterium FNCC 0083 joined with isolate of PSA10 and PPK6 on the similarity value $80.5 \%$ and $B$. cereus ATCC $14579^{\mathrm{T}}$ joined with the similarity value of $75.9 \%$.
The second cluster consisted of PPK5 isolate and $B$. subtilis ATCC $6051^{\mathrm{T}}$ with similarity value of $83.3 \%$. The third cluster is a single cluster consisted of B. pumilus ATCC 700814 and it is joined with the second cluster on similarity value of $58.4 \%$ (Figure 4).

Based on the similarity value between three local bacterial isolates with the reference strains were obtained from the cellular protein profiles in Table 4, showed that PSA10 isolate had a higher similarity to the $B$. megaterium FNCC 0083 with a similarity value of $83.3 \%$ compared with $B$. cereus ATCC $14579^{\mathrm{T}}$, while PPK6 isolate had a higher similarity to the B. cereus ATCC $14579^{\mathrm{T}}$ with the similarity value of $83.3 \%$. Isolate of PPK5 had a higher similarity to $B$. subtilis ATCC $6051^{\mathrm{T}}$ with similarity value of $83.3 \%$.
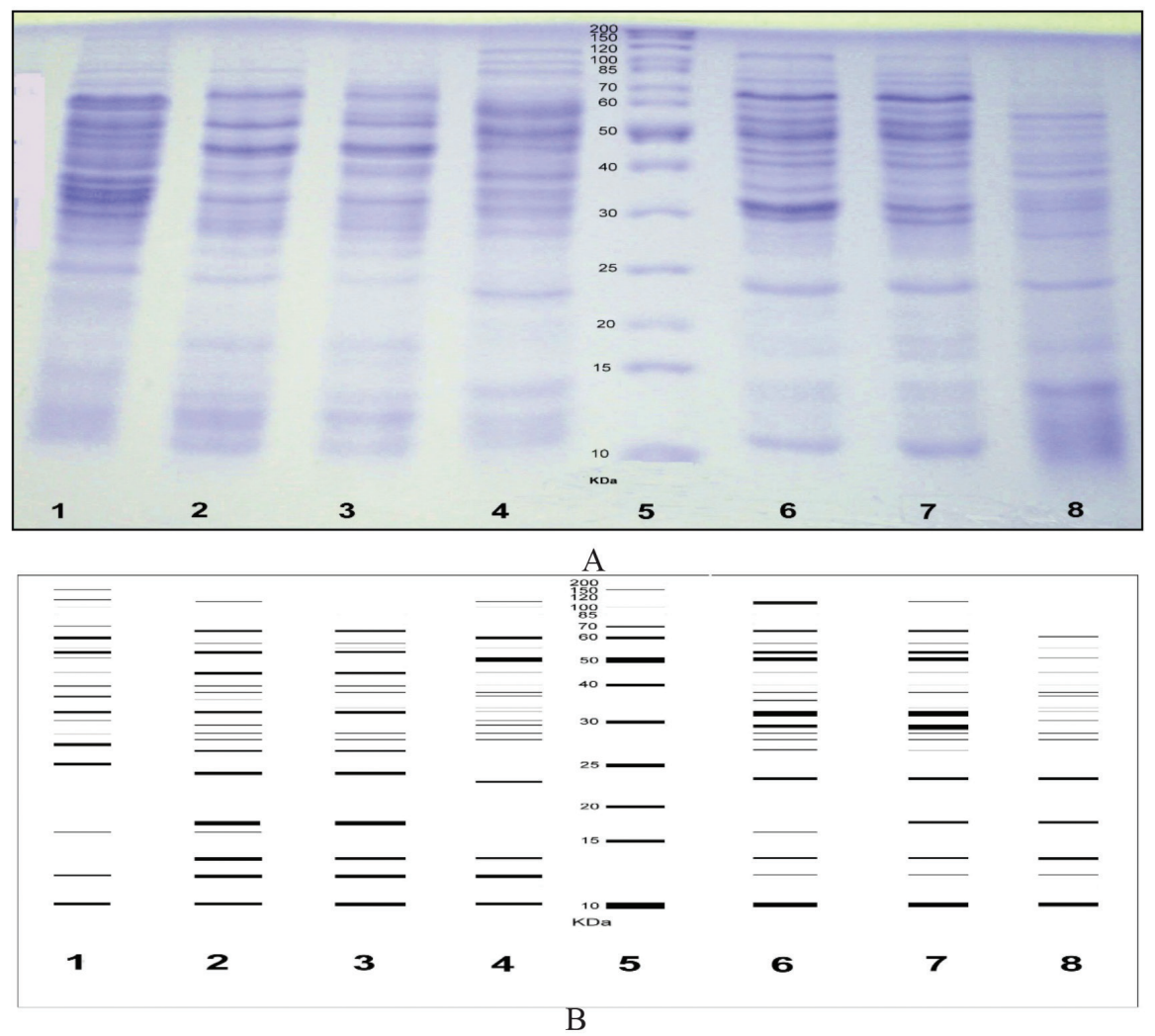

FIGURE 3. Whole-cell protein profiles of the local bacterial isolates and reference strains using SDS-PAGE electrophoresis. (A) The native of whole-cell protein profiles and (B) Diagramatic representative of whole-cellular protein profiles. Line 1 (B. pumilus ATCC 700814), Line 2 (B. megaterium FNCC 0083), Line 3 (B. cereus ATCC 14579 ), Line 4 (B. subtilis ATCC $6051^{\mathrm{T}}$ ), Line 5 (Marker), Line 6 (PSA10 isolate), Line 7 (PPK6 isolate), and Line 8 (PPK5 isolate)

TABLE 4. Matrix of percentage similarity between 3 local amylolytic bacteria isolates and 4 representatives of the Bacillus species based on whole-cell protein profiles

\begin{tabular}{lccccccc}
\hline & PPK5 & PPK6 & PSA10 & $\begin{array}{c}\text { B. subtilis } \\
\text { ATCC 6051 }^{\mathrm{T}}\end{array}$ & $\begin{array}{c}\text { B. cereus } \\
\text { ATCC 14579 }^{\mathrm{T}}\end{array}$ & $\begin{array}{c}\text { B. megaterium } \\
\text { FNCC 0083 }^{\text {ATC pumilus }}\end{array}$ & $\begin{array}{c}\text { B. pC 700814 } \\
\text { ATCC }\end{array}$ \\
\hline PPK5 & 100 & 63,9 & 47,2 & $\mathbf{8 3 , 3}$ & 63,9 & 47,2 & 52,8 \\
PPK6 & 63,9 & 100 & 83,3 & 63,9 & $\mathbf{8 3 , 3}$ & 77,8 & 44,4 \\
PSA10 & 47,2 & 83,3 & 100 & 58,3 & 66,7 & $\mathbf{8 3 , 3}$ & 50,0 \\
B. subtilis ATCC 6051 & $\mathbf{8 3 , 3}$ & 63,9 & 58,3 & 100 & 52,8 & 47,2 & 63,9 \\
B. cereus ATCC $14579^{\mathrm{T}}$ & 63,9 & $\mathbf{8 3 , 3}$ & 66,7 & 52,8 & 100 & 77,8 & 38,9 \\
B. megaterium FNCC 0083 & 47,2 & 77,8 & $\mathbf{8 3 , 3}$ & 47,2 & 77,8 & 100 & 33,3 \\
B.pumilus ATCC 700814 & 52,8 & 44,4 & 50,0 & 63,9 & 38,9 & 33,3 & 100 \\
\hline
\end{tabular}



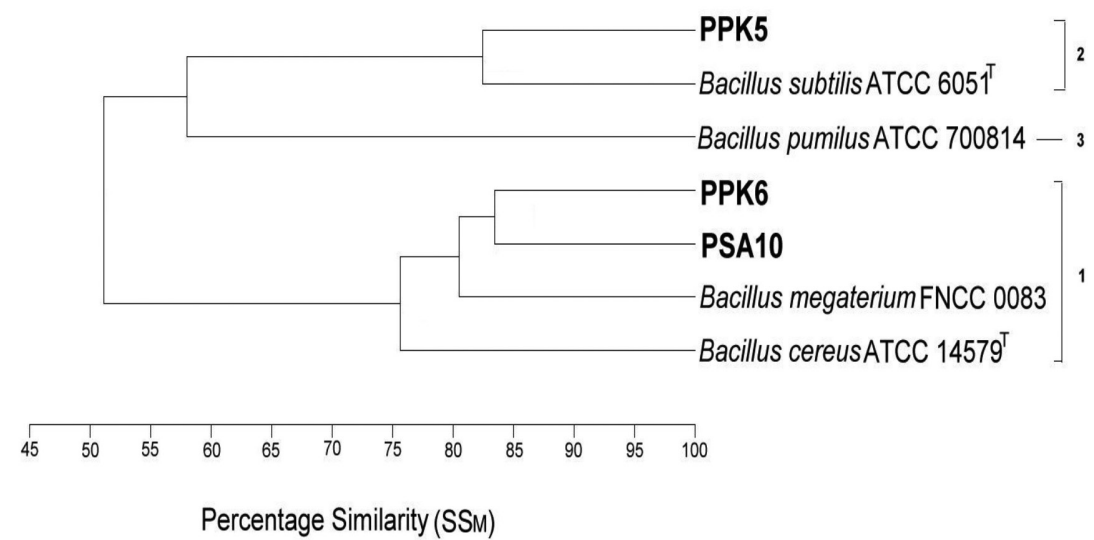

FIGURE. 4. The dendrogram showing the phenetic relationship between 3 local amylolytic bacteria isolates and 4 representatives of the Bacillus species based on simple matching coefficient $\left(\mathrm{SS}_{\mathrm{M}}\right)$ analysis and unweighted pair-group method with arithmetic average (UPGMA) algorithm based on chemical characters (whole-cell protein profile)

Berber and Yenidunya (2005) states that similarity value above $70 \%$ shows the high similarity level among bacterial strains. This indicated that PSA10 isolate is identic with $B$. megaterium, PPK6 isolate is identic with $B$. cereus and PPK5 isolate is identic with $B$. subtilis based whole-cell protein profiles.

Results of the study are shown in Figure 4 also showed that $B$. megaterium and B. cereus has a similarity higher than the B. subtilis and B. pumilus, while B. subtilis more similar to the $B$. pumilus compared to the other reference strains. The results are consistent with the grouping of members of the genus Bacillus species which showed that B. megaterium and B. cereus have a high similarity based on whole-cells protein profiles (Berber \& Yenidunya 2005), while $B$. subtilis and B. pumilus have a high similarity, so that they are grouped in the same group (cluster) (Berber \& Yenidunya 2005; O’Donnel et al. 1980). The results of this study indicate that the cellular protein profile by SDS PAGE method is accurate enough to use for bacterial identification.

The results of the study are consistent with previous studies, reporting that the whole-cell protein profiles using SDS-PAGE can be used for identification in some strains of bacterial genera members (Berber 2004; Berber \& Yenidunya 2005; Ghazi et al. 2009). Vandamme et al. (1996) and Ghazi et al. (2009) stated that the SDS-PAGE method can generate a complex pattern of protein bands and stable, so it can be used to interpret and compare the sample isolates with a reference strains.

Soluble cell protein produced by the method of SDSPAGE has proven reliable enough to distinguish the large number of strains and identification of microbial. SDSPAGE method has a discriminatory resolution to the level of species and subspecies (Vandamme et al. 1996). Finger printing of total protein using SDS-PAGE has been applied to differentiate strains of Xanthomonas (Vandamme et al. 1996; Vauterin et al. 1993), members of the genus Bacillus (Berber 2004; Berber \& Yenidunya 2005), members of Staphylococci (Santos et al. 2012), and the group of Lactic Acid Bacteria (Ghazi et al. 2009; Hong et al. 2014).
Thus, the identification of isolates of amylolytic bacteria producing of PHB using a whole-cell protein profiles by SDS-PAGE method, can strengthen the result of identification using phenotypic characters.

\section{IDENTIFICATION OF THE AMYLOLYTIC BACTERIA PRODUCING OF PHB BY GENOTYPIC CHARACTERS (16S RRNA GENE SEQUENCE) ANALYSIS}

Phylogeny tree on the analysis of 16S rRNA gene sequence of local bacterial strains with reference Bacillus strains, are shown in Figure 5 shows that there are three major clade. Clade A consisted of 5 small clade. PPK6 isolate joined with clade I and showed the closest kinship with $B$. cereus compared with $B$.thuringiensis, $B$. weihenstephanensis, $B$. mycoides, B. cohnii, B. halmaphalus and B. luciferensis (Figure 5). PSA10 isolate joined with clade II and PSA10 isolate closely related to B. megaterium compared with $B$. flexus (Figure 5).

Clade B comprised of B. subtilis, B. atrophaeus, $B$. amyloliquefaciens, $B$. licheniformis, $B$. pumilus and $B$. vallismortis and PPK5 isolate joined with this group (Figure 5). PPK5 isolate has the closest kinship with $B$. subtilis, compared with 5 other species (Figure 5). Clade C comprised of B. gibsonii, B. murimartini, B. clausii, B. pseudoalcaliphilus, B. pseudofirmus, B. firmus, B. agaradhaerens, and $B$. clausii.

The results of this study are consistent with previous research, which explained that B.cereus and B. megaterium are in one group, while $B$. subtilis are in a different group (Blackwood et al. 2004; Wang \& Sun 2009). B. megaterium was closely related to $B$. flexus, while $B$. cereus closely related with $B$. thuringiensis and $B$. subtilis closely related to B. amyloliquefaciens (Blackwood et al. 2004).

Some species are included in the clade B is known as a bacteria with high amylase activity, namely $B$. subtilis (Espino et al. 1997; Halami 2008), B. amylolyquefaciens (Apun et al.2000) and B. licheniformis (Mishra \& Behera 2008). PPK5 isolate which is a bacterial isolate with the highest amylase activity between the two other amylolytic 


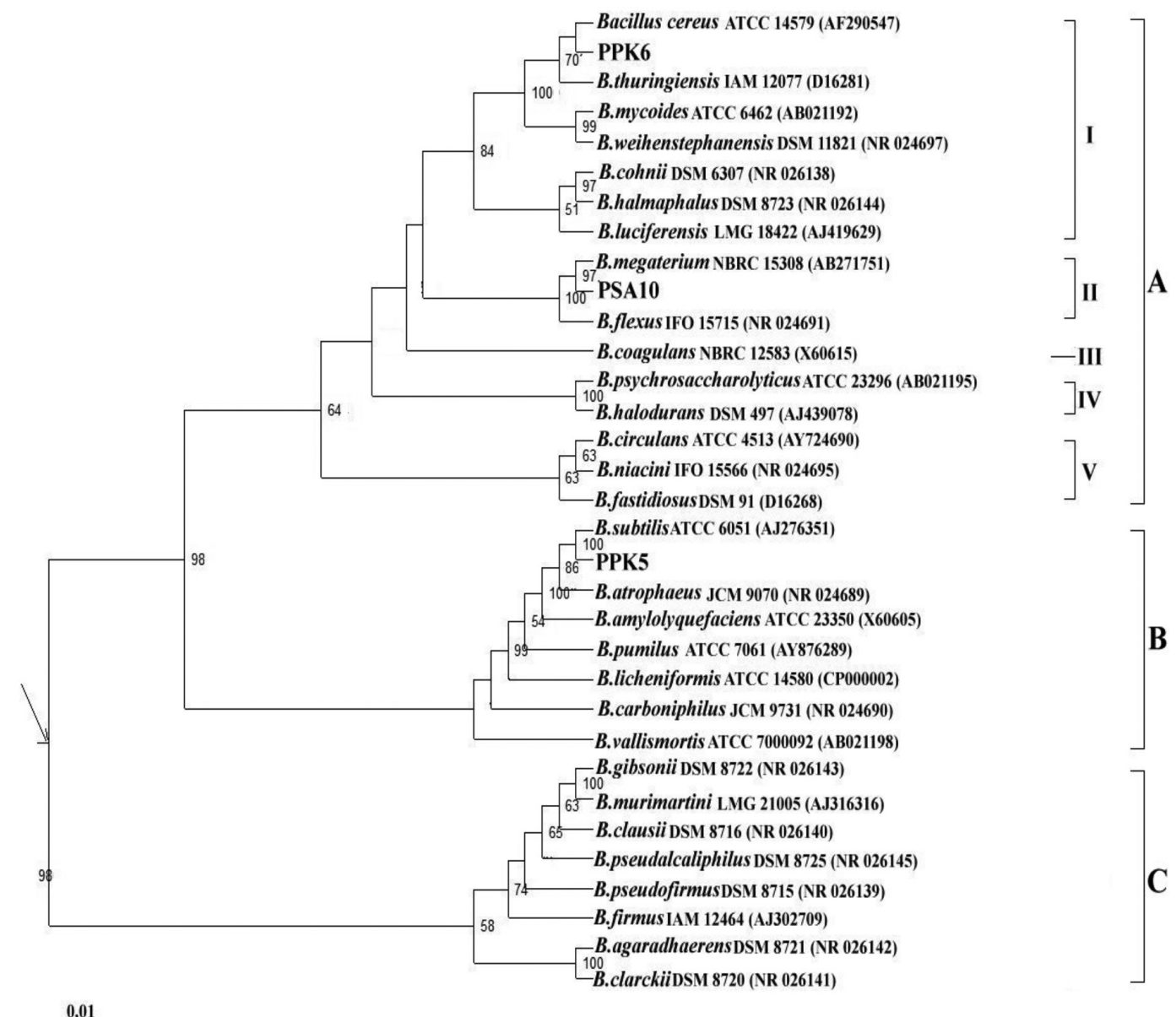

FIGURE 5. Phylogenetic tree showing relationships between the local amylolytic bacteria isolates (PSA10, PPK5, PPK6) and representatives species of the genus Bacillus based on 16S rRNA gene sequences. The scale bar indicates 1 nucleotide substitution per 100 nucleotides in 16S rRNA gene sequences. The numbers at nodes indicate the levels of bootstrap support (\%) based on a neighbor-joining analysis of 1000 resampled data sets. The arrow indicates the estimated root position of the tree

bacterial isolates (Table 1), joined with clade B and it is closely related to $B$. subtilis. This indicates that the strain of bacteria with high amylase activity joined with the group B. subtilis (clade B), although one of its members, namely $B$. pumilus is a bacteria that has no amylase activity (O’Donnel et al. 1980; Slepecky \& Hemphill 2006).

Isolate of PSA10 which is the highest PHB-producing bacterial strain, compared to both local amylolytic bacteria producing PHB (Table 1), was closely related to B. megaterium based on the analysis of 16S rRNA gene. This corresponds with the previous studies, which reported that B. megaterium is a bacteria that is known as the PHB producer who first investigated (Lenz \& Marchessault 2005; Visnuvardhan et al. 2008).

The analysis of $16 \mathrm{~S}$ rRNA gene sequence has become standard procedure to determine phylogenetic relationships between strains of bacteria (Blackwood et al. 2004; Vandamme et al. 1996; Wang \& Sun 2009). Identification of bacterial strains by sequence analysis of $16 \mathrm{~S}$ rRNA is more accurate, objective and allow a distinction between strains or species (Borsodi et al. 2007; Daroonpunt et al. 2018; Jamili et al. 2016b; Sembiring 2009). This method enough discriminating between bacterial species member of the genus Bacillus (Borsodi et al. 2007).

Identification of the three local amylolytic bacteria producing PHB with polyphasic approach based on characters of phenotypic, chemical (whole-cell protein profiles) and molecular (16S rRNA sequence) showed the congruence results. Several studies report that identification with the approach of systematics polyphasic using phenotypic, chemical and molecular characters can be used up to the species level (Lekota et al. 2016; Mainville et al. 2005; Randazzo et al. 2009) the suitability of the results (congruence) of these three approaches, which establishes the identity of the bacterial strains in the classification system (Vandamme et al. 1996).

\section{CONCLUSION}

The three local amylolytic bacteria producing bioplastic PHB from sago starch, namely PSA10, PPK5 and PPK6 isolates are member of genus Bacillus. PSA 10 isolate identical with Bacillus megaterium, PPK5 isolate identical with Bacillus subtilis and PPK6 isolate identical with 
Bacillus cereus based on phenotypic characters and wholecells protein profiles by numeric-phenetic analysis and these results supported by molecular analysis. Therefore, PSA10 isolate is a member of $B$. megaterium, PPK5 isolate is a member of $B$. subtilis and PPK6 isolate is a member of $B$. cereus based on identification with polyphasic approach.

\section{ACKNOWLEDGEMENTS}

The authors wish to thank to Fundamental research grant 2015-2016 by Indonesian Directorate General of Higher Education, Ministry of Research, Technology and Higher Education, Government of Indonesia, for the financial support.

\section{REFERENCES}

Apun, K., Jong, B.C. \& Salleh, M.D. 2000. Screening and isolation of a cellulolytic and amylolytic Bacillus from sago pith waste. J. Gen. App. Microbiol. 46: 263-267.

Aremu, M.O., Layokun, S.K. \& Solomon, B.O. 2010. Production of poly(3-hydroxybutyrate) from cassava starch hydrolysate by Pseudomonas aeruginosa NCIB 950. American $J$. Scientific and Industrial Research 1(3): 421-426.

Berber, I. 2004. Characterization of Bacillus species by numerical analysis of their SDS-PAGE protein profiles. J. Cell Mol. Biol. 3: 33-37.

Berber U. \& E. Yenidunya. 2005. Identification of alkaliphilic Bacillus species isolated from Lake Van and its surroundings by computerized analysis of extracellular protein profiles. Turk. J. Biol. 29: 181-188.

Blackwood, K.S., Turenne, C.Y., Harmsen, D. \& Kabani, A.M. 2004. Reassessment of sequence-based targets for identification of Bacillus species, J. Clinical Microbiology 42(4): 1626-1630.

Borsodi, A.K., Makk, J., Rusznya'k, A., Vajna, B., Taba, G. \& Ma'rialigeti, K. 2007. Phenotypic characterization and molecular taxonomic studies on Bacillus and related isolates from Phragmites australis periphyton. Aquatic Botany 86: 243-252.

Chee, J.Y., Yoga, S.S., Lau, N.S., Ling, S.C., Abed, R.M.M. \& Sudesh, R. 2010. Bacterially produced polyhydroxyalkanoate (PHA): Converting renewable resources into bioplastics. In Current Research, Technology and Education Topics in Applied Microbiology and Microbial Biotechnology, edited by Méndez-Vilas, A. Spain: Formatex Research Center. pp. 1395-1404.

Daroonpunt, R., Tanaka, N., Uchino, M. \& Tanasupawat, S. 2018. Characterization and screening of lipolytic bacteria from Thai fermented fish. Sains Malaysiana 47(1): 91-97.

Espino, T.M. \& Tambalo, R.D. 1997. Isolation, screening and characterization of high yielding $\alpha$-amylase producing bacteria. Annual Reports of IC Biotech. 20: 744-754.

Felsenstein, J. 1995. Phylip (Phylogeny Inference Package) Version $3.57 c$. Washington: University of Washington.

Ghazi, F., Henni, D.E., Benmechernene \& Kihal, M. 2009. Phenotypic and whole cell protein analysis by SDS-PAGE for identification of dominants lactic acid bacteria isolated from Algerian raw milk. World J. of Dairy and Food Sciences 4(1): 78-87.

Halami, P.M. 2008. Production of polyhydroxyalkanoate from starch by the native isolate Bacillus cereus CFR06. World J. Microbiol. and Biotechnol. 24: 805-812.
Holt, J.G., Krieg, N.R., Sneath, P.H.A., Stanley, J.T. \& Williams, S.T. 1994. Bergey's Manual of Determinative Bacteriology. 9th ed. Baltimore: Lipincot, Williams and Wilkins.

Hong, Y., Yang, H.S., Li, J., Han, S.K., Chang, H.C. \& Kim, H.Y. 2014. Identification of lactic acid bacteria in salted Chinese cabbage by SDS-PAGE and PCR-DGGE, J. Sci. Food Agric. 30(2): 296-300

Jamili, Yanti, N.A. \& Susilowati, P.E. 2016a. Diversity and the role of yeast in spontaneous cocoa bean fermentation from Southeast Sulawesi, Indonesia. Biodiversitas 17(1): 90-95.

Jamili, Yanti, N.A. \& Susilowati, P.E. 2016b. The indigenous lactic acid bacteria from fermented cocoa bean and its role in cocoa bean fermentation. Research Journal of Pharmaceutical, Biological and Chemical Sciences 7(5): 2268-2276.

Kovach Computing Service. 1990. Multi Variate Statistical Package, Version 3.1, Users' Manual.: http://www.kovcomp. $\operatorname{com} / /$.

Lenz, R.W. \& Marchessault, R.H. 2005. Bacterial polyesters: Biosynthesis, biodegradable plastics and biotechnology. Biomacromolecules 6(1): 1-8.

Lekota, K.E., Hassim, A., Mafofo, J., Rees, J., Muchadeyi, C.F., Van Heerden, H. \& Madoroba, E. 2016. Polyphasic characterization of Bacillus species from anthrax outbreaks in animals from South Africa and Lesotho. The Journal of Infection in Developing Countries 10(8): 814-823.

Logan, N.A., Forsyth, G., Lebbe, L., Goris, J., Heyndrickx, M., Balcaen, A., Verhelst, A., Falsen, E., Ljungh, A. Hansson, H.B. \& De Vos, P. 2002. Polyphasic identification of Bacillus and Brevibacillus strains from clinical, dairy and industrial specimens and proposal of Brevibacillus invocatus sp. nov. Inter. J. Syst. Evol. Microbiol. 52: 953-966.

Mainville, I., Robert, N., Lee, B. \& Farnworth, E.R. 2006. Polyphasic characterization of the lactic acid bacteria in kefir. Syst. and App. Microbiol. 29: 59-68.

Mishra, S. \& Behera, N. 2008. Amylase activity of a starch degrading bacteria isolated from soil receiving kitchen wastes. African J. Biotech. 7(18): 3326-3331.

O’Donnel, A.G., Norris, J.R., Berkeley, R.C.W., Claus, D., Kaneko, T., Logan, N.A. \& Nozak, R. 1980. Characterization of Bacillus subtilis, Bacillus pumilus, Bacillus licheniformis, and Bacillus amyloliquefaciens by pyrolysis gas-liquid chromatography, deoxyribonucleic acid-deoxyribonucleic acid hybridization, biochemical tests and API Systems. Inter. J. Syst. Bacteriol. 30(2): 448-459.

Ostle, A.G. \& Holt, J.G. 1982. Nile blue A as a fluorescent stain for poly- $\beta$-hydroxybutyrate. Applied and Environmental Microbiology 44(1): 238-241.

Priest, F.G., Goodfellow, M. \& Todd, C. 1988. A numerical classification of the genus Bacillus. J. Gen. Microbiol. 134: 1837-1882.

Randazzo, C.L., Scifo, G.O., Tomaselli, F. \& Caggia, C. 2009. Polyphasic characterization of bacterial community in fresh cut salads. International Journal of Food Microbiology 128: 484-490.

Ray, S. \& Kalia, V.C. 2016. Microbial cometabolism and polyhydroxyalkanoate co-polymers. Indian Journal of Microbiology 57(1): 39-47. DOI 10.1007/s12088-0160622-4.

Saitou, N. \& Nei, M. 1987. The neighbour-joining method: A new method for reconstructing phylogenetic trees. Molecular Biol. Evol. 4: 406-426. 
Santos, O.D., De Resende, M.C., De Mello, A.L., Frazzon, A.P. \& D'Azevedo, P.A. 2012. The use of whole-cell protein profile analysis by SDS-PAGE as an accurate tool to identify species and subspecies of coagulase-negative staphylococci. APMIS 120(1): 39-46.

Sarkono, Moeljopawiro, S., Setiaji, B. \& Sembiring, L. 2016. Analysis of whole cell protein profiles by SDSPAGE to identify indigenous celluloseproducer acetic acid bacteria. Indonesian Journal of Biotechnology 21(2): 86-92.

Scopes, R.K. 1987. Protein Purification. Principles and Practice. 2nd ed. New York: Springer Verlag.

Sembiring, L. 2009. Molecular phylogenetic classification of streptomycetes isolated from the rhizosphere of tropical legume (Paraserianthes falcataria) (L.) Nielsen. Hayati Journal of Biosciences 16(3): 100-108.

Shivakumar, S. 2012. Polyhydroxybutyrate (PHB) production using agro-industrial residue as substrate by Bacillus thuringiensis IAM 12077. Inter. J. ChemTech. Res. 4(3): 1158-1162.

Singh, M., Patel, K.S. \&. Kalia, V.C. 2009. Bacillus subtilis as potential producer for polyhydroxyalkanoates. Microbial Cell Factories 8: 38-49.

Smibert, R.M. \& Krieg, N.R. 1994. General characterization. In Manual of Methods for General Bacteriology, edited by Gerhardt, P., Murray, R.G.E., Wood, W.A. \& Krieg, N.R. Washington D.C.: American Society for Microbiology.

Slepecky, R.A. \&. Hemphill, H.E. 2006. The genus Bacillus-Non medical. Prokaryotes 4: 530-562.

Shivalkar, Y.K. \& Prabha, R. 2017. Polyhydroxybutyrate as biodegradable plastic - A review. IOSR Journal of Environmental Science, Toxicology and Food Technology 11(1): 10-12.

Song, J., Lee, S.C., Kang, J.W., Baek, H.J. \& Suh, J.W. 2004. Phylogenetic analysis of Streptomyces spp. isolated from potato scab lesions in Korea on the basis of 16S rRNA gene and 16S-23S rDNA internally transcribed spacer sequences. Inter. J. Syst. Evol. Microbiol. 54: 203-209.

Vandamme, P., Pot, B., Gillis, M., De Vos, P., Kersters, K. \& Swings. J. 1996. Polyphasic taxonomy, a consensus approach to bacterial systematics. Microbiological Rev. 60(2): 407-438.

Vauterin, L., Swings, J. \& Priest, F.G. 1993. Protein electrophoresis and classification. In Handbook of New Bacterial Systematics, edited by Goodfellow, M. \& O'Donnell, A.G. London: Academic Press Ltd. pp. 252-280.

Visnuvardhan, R.S., Thirumala, M., Kishore, R.T.V. \& Mahmood, S.K. 2008. Isolation of bacteria producing polyhydroxyalkanoates (PHA) from municipal sewage sludge. World J. Microbiol. Biotechnol. 10: 1-7.
Wang, W. \& Sun, M. 2009. Phylogenetic relationships between Bacillus species and related genera inferred from 16S rDNA sequences. Braz. J. Microbiol. 40: 505-521.

Yanti, N.A., Sembiring, L., Margino, S. \& Muhiddin, N.H. 2013. A study on production of poly- $\beta$-Hydroxybutyrate bioplastic from sago starch by indigenous amylolytic bacteria. Indonesian J. Biotech. 18(2): 144-150.

Yanti, N.A., Sembiring, L. \& Margino, S. 2009. Amilolytic bacteria producing of the raw material of bioplastic (in Indonesian). Berk. Penel. Hayati. 3C: 95-99.

Nur Arfa Yanti*, Sitti Wirdhana Ahmad \& Ardiansyah

Department of Biology

Faculty of Mathematics and Natural Science

Halu Oleo University

Kendari Southeast Sulawesi

Indonesia

L. Sembiring

Faculty of Biology

Gadjah Mada University

Yogyakarta

Indonesia

S. Margino

Faculty of Agricultural

Gadjah Mada University

Yogyakarta

Indonesia

Nurhayani H. Muhiddin

Faculty of Mathematics and Natural Science

Makassar State University, Makassar

South Sulawesi

Indonesia

*Corresponding author; email: nur.yanti@uho.ac.id

Received: 27 April 2019

Accepted: 25 September 2019 